\title{
The Case study of WTO Dispute Settlement on Value-Added Tax of Integrated Circuits between U.S. and China
}

\author{
YU LIU \\ Finance and Economic School, XI ZANG MIN ZU University, China \\ XIAN YANG City, 710082, China \\ Email:191017804@qq.com
}

Key Words: WTO Dispute Settlement, Value-Added Tax, U.S. , China

\begin{abstract}
This paper analyzes the case between U.S. and China Regarding China's Tax on Integrated Circuits. It evaluates on a country-by-country basis how they have fared in the specific case in which they were involved and in advancing their major trade policy concerns. Finally, it explores key issues and suggests a research agenda for the future. This study provides practical guidelines for WTO Dispute Settlement between countries.
\end{abstract}

\section{Introduction}

Since China joined the WTO in December 2001, the United States has had a number of concerns regarding China's WTO i mplementation. Substantial progress has been made in areas such as agricultural biotechnology, express delivery, insurance and auto financing rules without having to go through the WTO dispute settlement process. However, The United States has repeatedly engaged China regarding its integrated circuit VAT rebate policy in an attempt to resolve the issue. These efforts have not succeeded. Finally, on 23 March, 2004, The United States filed a complaint with the WTO's dispute settlement body concerning Beijing's tax treatment of semiconductors. This is the first WTO case filed against China by any WTO Member.

This paper analyzes the case between U.S. and China Regarding China's Tax on Integrated Circuits. It evaluates on a country-by-country basis how they have fared in the specific case in which they were involved and in advancing their major trade policy concerns. Finally, it explores key issues and suggests a research agenda for the future. This study provides practical guidelines for WTO Dispute Settlement between countries.

\section{The Case Regarding China -VAT on Integrated Circuits}

1. Case Review

On 18 March 2004,WASHINGTON -U.S. Trade Representative Robert B. Zoellick announced that the United States has filed a case at the World Trade Organization(WTO) regarding China's discriminatory tax rebate policy for integrated circuits. This action begins a 60-day consultation period required under WTO rules.The United States claims that, although China provides for a 17 percent VAT on ICs, enterprises in China are entitled to a partial refund of the VAT on ICs that they have produced, resulting in a lower VAT rate on their products. In the US view, China thus appears to be subjecting imported ICs to higher taxes than applied to domestically produced ICs and to be according less favorable treatment to imported ICs. In addition, the United States claims that China allows for a partial refund of VAT for domestically-designed ICs that, because of technological limitations, are manufactured outside of China. In the US view, China thus appears to be providing for more favourable treatment of imports from one Member than from others, and also is discriminating against services and service suppliers of other Members.

The United States considers that these measures are inconsistent with the obligations of China under Articles I and III of the GATT 1994, the Protocol on the Accession of the People's Republic of China (WT/L/432), and Article XVII of the GATS.

On 26 March 2004, the European Communities requested to join the consultations. On 31 March 2004, Japan requested to join the consultations. On 1 April 2004, Mexico and the Separate 
Customs Territory of Taiwan, Penghu, Kinmen and Matsu requested to join the consultations. On 28 April 2004, China informed the DSB that it had accepted the requests of the European Communities, Japan and Mexico to join the consultations.

On 14 July 2004, China and the United States notified the DSB that they had reached an agreement with respect to the matter raised by the United States in its request for consultations. According to the notification, China agreed to amend or revoke the measures at issue to eliminate the availability of VAT refunds on ICs produced and sold in China and on ICs designed in China but manufactured abroad by 1 November 2004 and 1 September 2004 respectively. The effective dates are 1 April 2005 and 1 October 2004 respectively.

On 5 October 2005, China and the United States informed the DSB that they were in agreement that the terms of the agreement had been successfully implemented, and thus they had agreed that a mutually satisfactory solution had been reached to the matter raised by the United States.

2. Major Issues Raised by the United States

(1) Discriminatory application of VAT

The Semiconductor Industry Association (SIA) objections are directed at the discriminatory application of China's VAT.USA has advocated lowering the VAT rate to 3 percent - the effective VAT rate on domestically produced semiconductors after rebates - on all semiconductors, regardless of origin. Equalizing the VAT burden on domestic and imported semiconductors removes the discrimination and allows China to avoid a negative finding in the WTO case.

The VAT regime as presently applied levies a VAT tax of 17 percent on sales of all imported and domestically produced semiconductors. However, Chinese government provides for a rebate of the amount of the VAT burden in excess of 3 percent for semiconductors manufactured within China and for the amount of the VAT burden in excess of 6 percent for semiconductors manufactured abroad from chip designs developed in China. The discriminatory application of China's VAT amounts to a de facto tariff on imported semiconductors and is inconsistent with China's obligations under the WTO. China eliminated its tariffs on semiconductors when it joined the WTO in December 2001. The differential VAT policy is in effect taking back those tariff concessions and creating a market access barrier.

(2) National Treatment Obligation and China's VAT Policy

The United States believes that this discriminatory tax policy is inconsistent with the national treatment obligations that China assumed when it joined the WTO in December 2001.By granting preferential tax treatment to domestic semiconductor products and designs, China is not providing national treatment with respect to these goods and services as required by the WTO. GATT Article III on National Treatment prohibits internal taxation and regulation that discriminates in favor of domestic products at the expense of imports. In China's WTO Accession Protocol, China specifically agreed to "ensure that internal taxes and charges, including value-added taxes, applied or administered by national or subnational authorities shall be in conformity with the GATT 1994." This express commitment was a direct result of WTO members expressing concern, during negotiations with China, "that some [Chinese] internal taxes applied to imports, including a value added tax ('VAT') were not administered in conformity with the requirements of GATT 1994, particularly Article III." Accordingly, the DSU consultations over the discriminatory VAT rebate policy should not be a surprise to high ranking Chinese government officials. China must abide by the central principle of national treatment required as a WTO member, and fulfill the specific commitments made in its Accession Protocol.

(3) Competitive business of the semiconductor industry.

The semiconductor industry is a tremendously competitive business. A small difference in price - certainly much less than the significant difference resulting from the discrimination created by China's application of its VAT rebate program - can make the difference between winning and losing a sale. As a result of the refund policy, the effective VAT rate on domestic products can be as low as 3 percent. China also allows for a partial refund of VAT paid on integrated circuits designed in China but manufactured abroad. The significant differential in tax burden created by China's application of a discriminatory VAT rebate scheme is a very large burden that foreign 
semiconductor manufacturers and designers cannot overcome when selling products in China. US believe that this policy is also inconsistent with China's international trade obligations.

(4) Discriminatory VAT and Foreign Investment

China's discriminatory application of its VAT is also severely and unfairly skewing investment patterns. China's semiconductor industry attracted $\$ 3.6$ billion of new investment from 2000 to 2002, and investment is projected to reach $\$ 12$ billion by 2005 and $\$ 25$ billion by 2013. Research undertaken by SIA indicates that the VAT rebate is a major factor in investment decisions. The SIA represents the $\$ 80$ billion U.S. semiconductor industry. SIA member companies comprise approximately 85 percent of U.S.-based semiconductor production. Therefore, the United States believes that China's current VAT rebate policy not only discriminates against U.S. products directly, but also distorts international investment in the integrated circuit sector.

3. Respondents by China and Dispute Settlement

Beijing's initial reaction was to express surprise rather than to launch a rebuttal. The Ministry of Commerce pointed out that the US and China had been making progress on the issue of the value added tax on semiconductors as a result of several rounds of talks. "In the normal course of bilateral consultations, the US side suddenly raised a request under the WTO dispute resolution mechanism. China really does not understand this," said a Ministry spokesman. Beijing has since made a number of counter claims, including the assertion that China already imports over 80 percent of its semiconductors and therefore has a de facto open market. Chinese officials have also made the point that the tax rebate has not been of substantial benefit to domestic manufacturers, and that the inequitable treatment has not materially affected foreign suppliers. Obviously, China's application of its VAT regime is a clear violation of its WTO obligations.

On the face of it, the arguments are strongly in favor of the United States. If the case goes to a WTO dispute settlement panel, the finding will likely be that the Chinese tax rebate is a violation of GATT Article III, which prohibits the use of internal taxes in a fashion that discriminates between domestic and imported goods. Chinese government lawyers know this issue well. Therefore, after China and the United States holding constructive consultations on 27 April 2004 in Geneva and bilateral meetings in Washington and Beijing; China and the United States have reached an agreement with respect to the matter raised by the United States in document WT/DS309/1 (ChinaValue-Added Tax on Integrated Circuits) dated 18 March 2004. China and the United States have agreed as follows:

By 1 November 2004, China will amend the measures described in the US consultation request (WT/DS309/1) to eliminate the availability of VAT refunds to firms producing ICs in China on their domestic sales. The effective date of these amendments will be no later than 1 April 2005 . Until the effective date of these amendments, VAT refunds will be available only to integrated circuit enterprises certified under the measures as of 14 July 2004 in respect of products so certified as of 14 July 2004.

By 1 September 2004, China will issue a notice to revoke the measure described in the US consultation request (WT/DS309/1) that provides for VAT refunds on ICs designed in China but manufactured abroad. The effective date of revocation will be no later than 1 October 2004.

6 October 2005, China and the United States notified the Dispute Settlement Body ("DSB") that they have reached a mutually satisfactory solution. The resolution will ensure full market access and national treatment for U.S. integrated circuits in China, the world's fastest growing semiconductor market and an export market worth over \$2 billion to American manufacturers and workers. This agreement resolves the first WTO case filed against China by any WTO Member.

\section{Discussions and Implications}

\section{Discussions}

One of the guiding principles of the WTO is that countries and consumers benefit most when products have fair and equal access to markets without regard to their national origin. Policies that discriminate against products on the basis of national origin distort both purchasing and investment decisions to the detriment of everyone. While WTO rules permit countries to provide certain types 
of assistance to domestic industries, they prohibit WTO members from supporting their industries by discriminating against foreign products. The following is the experience of China in this trade dispute.

First, this is the first legal challenge for China after two years joining WTO. Despite the rhetoric, the semiconductor case should not be interpreted as a sign of US-China trade relations coming dangerously to a boil. Since China's accession to the WTO, the two sides have actually made substantial progress on such disputes as agricultural biotechnology, express delivery, insurance and auto financing, without having to go to the WTO. Indeed, this case is the first that any WTO member has brought against China (China was, however, party to a case brought against the US), and it may not even go the whole legal distance. That the Americans have chosen semiconductors as their test case rather than any number of other potential challenges probably reflects the desire for an "easy win" in the WTO, rather than a policy shift to "get tough" with China.

Second, this is an opportunity for Chinese officials to gain first-hand experience in the dispute settlement mechanism, whatever the outcome. China has long argued that developed countries have used international economic institutions to their benefit. Now that China is part of the WTO club, the opportunity to take advantage of WTO rules (such as contingent protection) has not been lost on the Chinese leadership.

Third, a full-blown trade war is an inevitable implication of failure to reach a successful outcome in Geneva. According to this case, China decides on other priorities and simply fails to take advantage of the dispute as an opportunity to complement its ongoing domestic reform strategies. It may thus be important to manage expectations about what WTO dispute settlement can accomplish.

Finally, one way for Beijing to increase Chinese confidence in the WTO system is to go on the offensive and initiate some disputes of its own. As the number of new WTO disputes initiated against China continues to rise and Beijing begins to lose some of them in Geneva, there is the inevitable threat of backlash within China. Some domestic groups will focus excessively on what will appear to be a one-sided dispute settlement process that sees China only as a target. There will be calls for China to withdraw from such an unfair system. Perhaps surprisingly, such calls have been heard periodically even in the United States, when U.S. policies were challenged and it lost case after case. For the United States, however, muting the critics was fairly straightforward-all that was needed was to remind them of the other half of the data. In almost as many disputes that it has been a defendant and legally "lost," the United States has taken on the role of plaintiff, challenged other countries' policies, legally "won," and improved foreign market access for its exporters.Thus, one way for Beijing to increase Chinese confidence in the WTO system is to go on the offensive and initiate some disputes of its own, in part to balance public perception of its role within the institution.

2 Implications

The foregoing discussion suggests that there is still need for more training and assistance to developing countries to enable them to handle the initial stages of dispute settlement more effectively. The establishment of the Advisory Centre on WTO Law and the dispute settlement training activities of the WTO Secretariat and others should help ensure that developing countries continue to made progress on this front.

In addition, although WTO members have expressed general satisfaction with the operation of the WTO dispute settlement system, the system has been under almost constant review for possible reforms since 1998 in considering what sort of DSU reforms should be of interest to developing countries.

\section{Acknowledgement}

In this paper, the research was sponsored by the Major Project Cultivation Program of XI ZANG MIN ZU University (Project No.). 


\section{Reference}

[1]. Accession of the People’s Republic of China, WT/L/432, Part I, Sec. 11(2)

[2]. Bown (2002), “The Economics of Trade Disputes, the GATT's article XXIII, and the WTO's Dispute Settlement Understanding,” Economics and Politics, 14(3):283-323.

[3]. Chad P. Bown, (2009), U.S.-China Trade Conflicts and the Future of the WTO, vol.33:1 winter/spring 2009

[4]. Comments of the Semiconductor Industry Association WTO Dispute Settlement Proceeding Regarding China -Value-Added Tax on Integrated Circuits May 17, 2004, Semiconductor Industry Association

[5]. Fabien BESSON\& Racem MEHDI, (2004), Is WTO Dispute Settlement System Biased Against Developing Countries? An Empirical Analysis Working Paper, available at:www.ecomod.net/conferences/ecomod2004/_papers/199.pdf

[6] .Federal Register (2004)/ Vol. 69, No. 77 / Wednesday, April 21, 2004 / Notices

[7].Petersmann, E.U. (1997), The GATT/WTO Dispute Settlement System : International Law, International Organizations and Dispute Settlement, London: Kluwer Law International.

[8]. See WTO, “Accession of the People’s Republic of China,” 23 November 2001, $<$ http://docsonline.wto.org/imrd/directdoc.asp?DDFDocuments/t/WT/L/432.doc>

[9].William J. Davey, The WTO Dispute Settlement System, in Gary P. Sampson \& W. Bradnee Chambers (eds.), Trade, Environment and the Millennium 145-174 (United Nations University Press 2d ed. 2002);

[10]. William J. Davey, "The WTO Dispute Settlement Mechanism" (June 25, 2003), Illinois Public Law Research Paper No. 03-08, http://ssrn.com/abstract=419943. 